\title{
7. A HIGH-RESOLUTION STRATIGRAPHY FOR PLEISTOCENE SEDIMENTS FROM NORTH PACIFIC SITES 881, 883, AND 887 BASED ON ABUNDANCE VARIATIONS OF THE RADIOLARIAN CYCLADOPHORA DAVISIANA ${ }^{1}$
}

\author{
Joseph J. Morley, ${ }^{2}$ Victoria L. Tiase, ${ }^{3}$ Michael M. Ashby, ${ }^{4}$ and Michaele Kashgarian ${ }^{5}$
}

\begin{abstract}
The abundance pattern of the radiolarian species Cycladophora davisiana davisiana was constructed in Pleistocene sediments at three North Pacific Leg 145 sites. At northwest Pacific Site 883 and Gulf of Alaska Site 887, this species' abundance pattern in combination with specific biostratigraphic datum levels provided a detailed stratigraphic framework which enabled the identification of missing sediment intervals as well as placement of the discontinuous isotopic sections from Site 883 into their proper stratigraphic sequence. Development of a nearly continuous $C$. davisiana davisiana record at Site 881 extended documentation of this species' abundance variations into the middle Pleistocene.
\end{abstract}

\section{INTRODUCTION}

An objective of Leg 145 was to acquire a set of detailed oxygen and carbon isotopic records from the high-latitude North Pacific so as to determine what role this region played in water-mass formation during the last several glacial/interglacial cycles. Preliminary analysis of sediments from Leg 145 sites indicates that only a partial oxygen isotope history of the late Pleistocene can be constructed because of the low abundance or complete absence of foraminifers throughout significant portions of the cores.

Previous studies have shown that the abundance pattern (relative percentage) of the radiolarian species Cycladophora davisiana davisiana in combination with specific biostratigraphic datum levels provides a high-resolution siliceous stratigraphy in high-latitude Pleistocene marine sediments. Therefore, one of the purposes of this study was to generate the late Pleistocene $C$. davisiana davisiana abundance pattern at Sites 883 and 887 (Table 1; Fig. 1) in order to determine the duration of various gaps in the isotopic records so that the oxygen isotope slices could be placed in their proper stratigraphic framework.

The other major objective of this study was to extend the documentation of the $C$. davisiana davisiana abundance pattern beyond its present limit of $\sim 0.5 \mathrm{Ma}$ so as to provide a high-resolution stratigraphy for older Pleistocene sequences. The piston coring techniques employed by the Ocean Drilling Program (ODP) make it possible, at least in theory, to acquire an entire sediment record from a specific site. Such continuous recovery of the sediment record is crucial for documentation of the pattern of any continuous high-resolution variable (biological, geochemical, or sedimentological). For this portion of our study, we selected the sediment record from Leg 145 with the highest late Pleistocene sedimentation rate and the best biogenic silica preservation (Site 881; Table 1, Fig. 1).

\section{BACKGROUND}

High-latitude marine sediments record some of the most striking changes in Pleistocene climate. Unfortunately, establishing a stratigraphic framework for these records is difficult because marine sequences from these regions are often devoid of calcium carbonate,

' Rea, D.K., Basov, I.A., Scholl, D.W., and Allan, J.F. (Eds.), 1995. Proc. ODP, Sci Results, 145: College Station, TX (Ocean Drilling Program).

232 West End Avenue, Westwood, NJ 07675, U.S.A.

${ }^{3} 21$ Euclid Avenue, Westwood, NJ 07675, U.S.A.

${ }^{4}$ 177-50 106th Avenue, Jamaica, NY 11433, U.S.A

${ }^{5}$ Lawrence Livermore National Laboratory, Livermore, CA 94551, U.S.A. making it impossible to construct a detailed chronology based on oxygen isotope variations. Initial studies of the abundance variations of a specific radiolarian species in subantarctic sediments indicated that the abundance pattern of one of these species, C. davisiana davisiana, might serve as an adequate substitute high-resolution stratigraphy in high-latitude, low-carbonate sediments (Hays et al., 1976b).

C. davisiana davisiana is a cosmopolitan species, present in all radiolarian-bearing sediments from all major oceans and most marginal seas (Morley and Hays, 1983). This extant species first occurs in upper Pliocene sediments from the North Pacific at $2.7 \mathrm{Ma}$ (Morley, 1985). The percentage of $C$. davisiana davisiana relative to all other radiolarians rarely exceeds $5 \%$ in Holocene sediments, sediment-trap and plankton-tow samples. At numerous times throughout the late Pleistocene, however, it reaches abundance levels in excess of $20 \%$ of the total radiolarian fauna at high-latitude $\left(>40^{\circ}\right)$ sites in both hemispheres. The exact causes of such variations are still not known, but sea-surface temperature does not appear to be the dominant controlling factor (Hays et al., 1976b; Morley and Hays, 1983).

An initial comparison of $C$. davisiana davisiana records with their corresponding oxygen isotope curves showed that relative abundance changes of this species, for the most part, maintained the same stratigraphic position with respect to the oxygen isotope curve (Hays et al., $1976 \mathrm{a}, \mathrm{b})$. The results of these first studies of subantarctic and Antarctic sediments also indicated that the abundance variations of $C$. davisiana davisiana contained nearly as much stratigraphic information as its isotopic counterpart (Fig. 2, see plots for composite record from Core RC11-120 and E49-18).

Comparison of this species' abundance pattern with oxygen isotope records in the North Atlantic (Morley and Hays, 1979) showed that the relative abundance variations of $C$. davisiana davisiana were not only similar within the North Atlantic, but that changes in this species' abundance appeared to be synchronous between the two hemispheres. In the North Pacific, the $C$. davisiana davisiana pattern has been correlated with an incomplete and limited oxygen isotope record from the Tenchi Seamount (Core V20-119). Because of the low sedimentation rate $(<10 \mathrm{~m} / \mathrm{m} . \mathrm{y}$.) and the absence of foraminifers at most intervals, this correlation was limited to approximately the last $0.03 \mathrm{~m} . \mathrm{y}$. and a portion of the last interglacial period (N.J. Shackleton and J.J. Morley, unpubl. data, 1980). However, extensive comparison of $C$. davisiana davisiana's relative abundance pattern with discrete ash layers and floral and faunal datum levels in a suite of North Pacific cores showed that this species exhibited abundance variations during the late Pleistocene comparable with those reported from the subantarctic and North Atlantic (Fig. 2), with the major features of its abundance pattern apparently being synchronous within the high- 
Figure 1. Location of Leg 145 sites for which sediments were analyzed in this study.

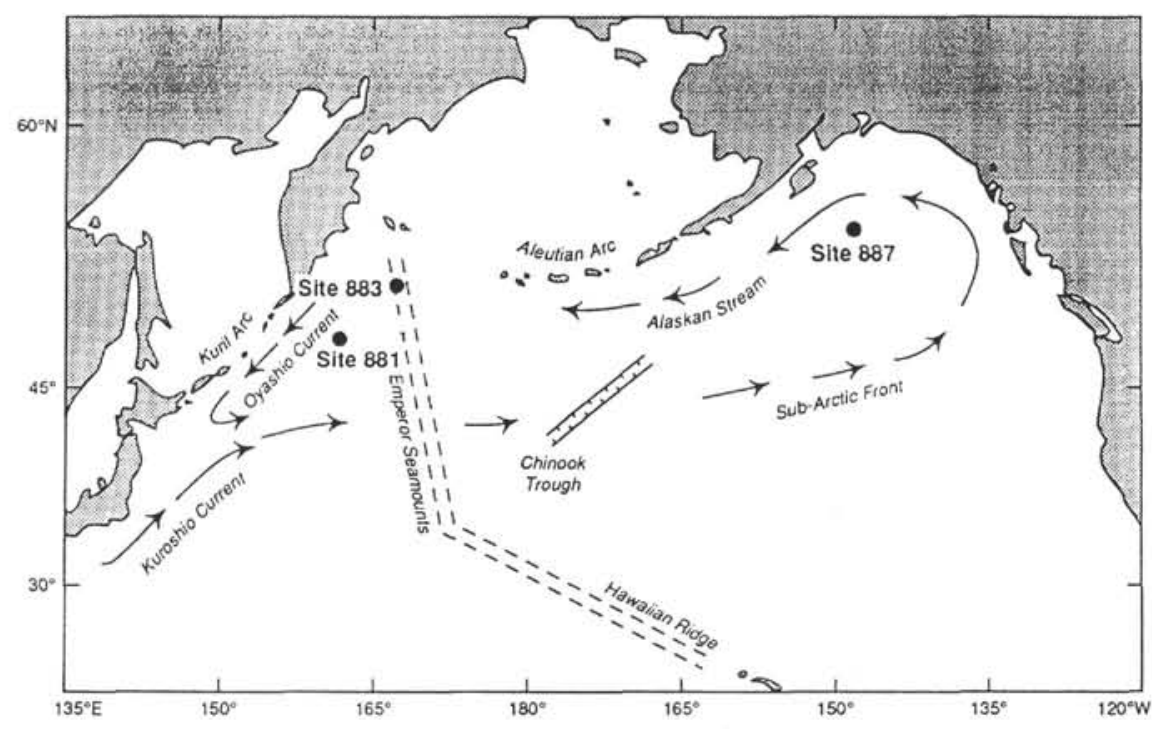

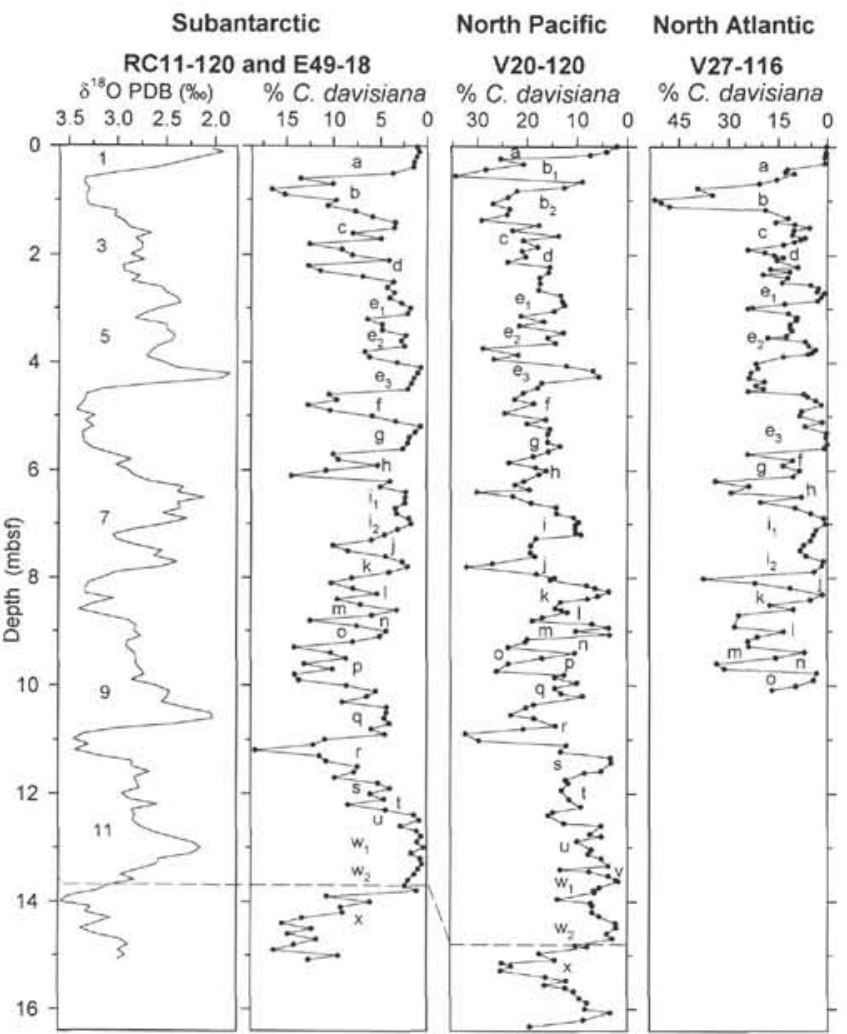

Figure 2. Abundance variations (relative percentage) of $C$. davisiana davisiana in cores from the subantarctic (Hays et al., 1976a), North Pacific (Morley et al., 1982) and North Atlantic (Morley and Hays, 1979) along with oxygen isotope measurements from the subantarctic composite record (RCl1-120 and E49-18) vs. depth (meters below seafloor). Interglacial isotopic stages are numbered; $C$. davisiana davisiana minima and maxima are lettered; last occurrence of radiolarian Stylatractus universus indicated by dashed line in subantarctic and North Pacific sites.

latitude North Pacific, North Atlantic, and Southern oceans (Morley et al., 1982).

Because of its apparent stratigraphic value, previous efforts have been made to extend the well-documented, high-latitude $C$. davisiana davisiana abundance pattern beyond its present $\sim 0.5 \mathrm{Ma}$ limit based on detailed analyses of high-sedimentation-rate piston core records.
During Deep Sea Drilling Project (DSDP) Leg 86, a nearly complete sediment sequence with high-sedimentation rates $(>50 \mathrm{~m} / \mathrm{m} . \mathrm{y}$.) was acquired at Site 580 in the northwest Pacific. The construction of the C. davisiana davisiana abundance curve from this site extended the record of this species' faunal abundance variations back through the entire Pleistocene (Morley, 1985). However, because only a single hole was taken at this site, the $C$. davisiana davisiana record (Fig. 3) contained missing portions of indeterminate lengths at most breaks between cores.

\section{PROCEDURES AND ANALYSES}

Sediments from the upper 19.4 mbsf of Hole $883 \mathrm{~B}$ were taken at $\sim 35-\mathrm{cm}$ intervals. The upper $34 \mathrm{mbsf}$ from primary Hole $887 \mathrm{~B}$ was sampled at $\sim 40-\mathrm{cm}$ intervals, whereas at Hole $887 \mathrm{~A}$ samples of much of the upper $34.8 \mathrm{mbsf}$ were taken at intervals of $\sim 35 \mathrm{~cm}$. At Site 881 , Hole $881 \mathrm{~B}$ was selected as the primary hole; it was sampled at $\sim 30-\mathrm{cm}$ intervals throughout the middle and late Pleistocene sequence. Samples from Holes $881 \mathrm{~A}$ and $881 \mathrm{C}$ were also taken at $\sim 30-\mathrm{cm}$ intervals in designated sections to close missing intervals between cores from Hole 881 B. The procedures described by Moore (1973) were followed in preparing slides on which radiolarians were randomly settled.

The relative percentage of $C$. davisiana davisiana was determined in each sediment sample based on, in all but a few instances, a minimum count of 300 radiolarians. In addition to calculating the percentage $C$. davisiana davisiana, a presence/absence survey was conducted in each sample for several species that have become extinct within the last million years. The youngest of these events, the last occurrence (LO) of the radiolarian Lychnocanoma nipponica sakaii (L. sp. cf. L. grande), is restricted to the North Pacific (Kruglikova, 1976; Robertson, 1975). Robertson (1975) arrived at an estimated age for this event by interpolating between the most recent $C$. davisiana davisiana abundance peak (corresponding to the last glacial maximum $\sim 0.018 \mathrm{Ma}$ ) and the LO of the diatom Simonseniella curvirostris at 0.026 (Donahue, 1970). More recent studies by Morley et al. (1982), using the abundance pattern of $C$. davisiana davisiana as well as the LO of the radiolarian Stylatractus universus and numerous ash layers in a series of North Pacific cores, also calculated an age of $\sim 0.05 \mathrm{Ma}$ (Cande and Kent [1992] time scale) for this event.

The LO of the cosmopolitan species Stylatractus universus was also identified in our records. This event has been shown to be globally synchronous (Hays and Shackleton, 1976; Morley and Shackleton, 1978), occurring within the glacial/interglacial transition between oxygen isotope Stages 12 and 11. The age of this event, using the time scale of Cande and Kent (1992), is 0.45 Ma. 


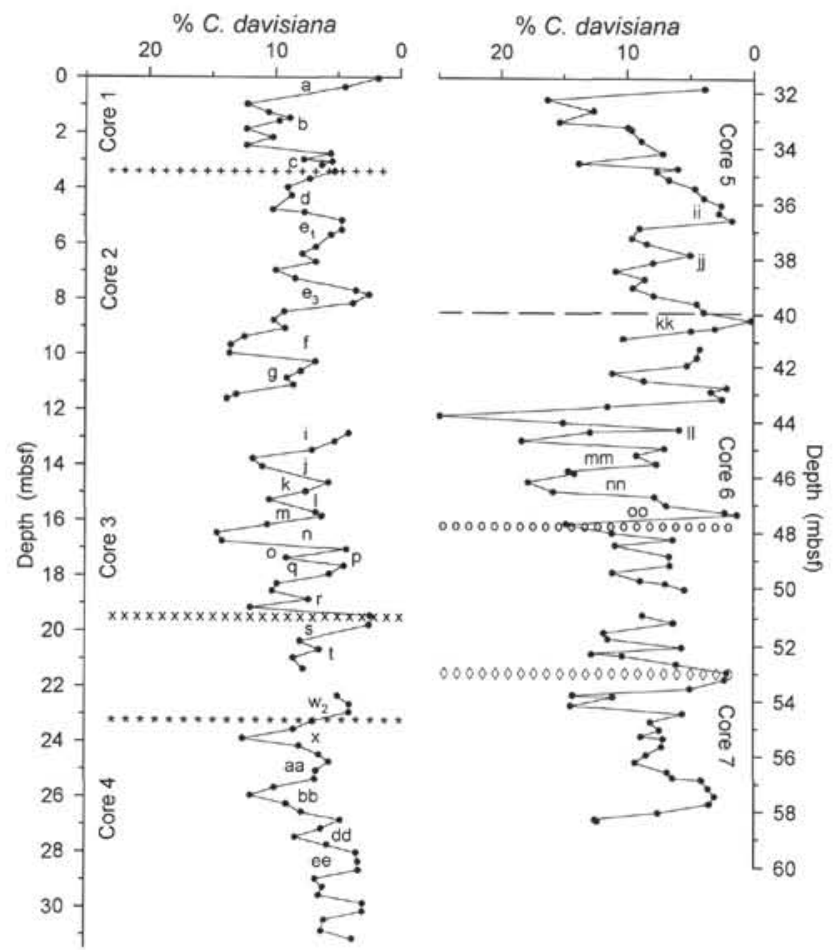

Figure 3. Cycladophora davisiana davisiana abundance pattern (relative percentage) in sediments from first seven hydraulic piston cores ( $\sim 1$ m.y.) from northwest Pacific DSDP Hole $580\left(41^{\circ} 37.47^{\prime} \mathrm{N}, 153^{\circ} 58.58^{\prime} \mathrm{E}\right)$ vs. depth (meters below seafloor). Letter identification of $C$. davisiana davisiana abundance minima and maxima in the upper $24 \mathrm{~m}$ follows that of Morley et al. (1982); minima and maxima below this level are added here for comparison with record from Leg 145 Site 881 . Unconnected data points mark position of boundaries between individual cores. Line of +'s = last occurrence of radiolarian $L$. nipponica sakaii ( $L$. sp. cf. $L$ grande); $\times$ 's = last occurrence of radiolarian $S$. acquilonium; $*$ 's = last occurrence of radiolarian $S$. universus; dashed line = Brunhes/Matuyama boundary; open circles = Matuyama/Jaramillo boundary; open diamonds = Jaramillo/Matuyama boundary.

Another radiolarian biostratigraphic event identified in our records was the LO of Stylacontarium acquilonium. Like L. nipponica sakaii, S. acquilonium is only found in North Pacific sediments. The age of this datum level was first estimated by Hays and Ninkovitch (1970) at $0.31 \mathrm{Ma}$, but this age was later revised to $0.35 \mathrm{Ma}$ (Cande and Kent [1992] time scale), based on a more accurate age estimate of $S$. universus from correlation with the global oxygen isotope stratigraphy (Morley et al., 1982).

The LO of the diatom Simonseniella curvirostris was also located in sediments from Hole 883B. The age of this event based on the Cande and Kent (1992) time scale is $0.30 \mathrm{Ma}$ (Shipboard Scientific Party, 1993a).

In addition to these biostratigraphic events, two Accelerator Mass Spectrometry (AMS) dates for the upper sequences from Hole 883D and two magnetic reversal boundaries recorded in sediments from Site 881 (Shipboard Scientific Party, 1993b) provided chronological control. Table 2 gives the specifics for each of these discrete events.

\section{RESULTS}

\section{Site 883}

The abundance variations of $C$. davisiana davisiana from the upper $19.41 \mathrm{mbsf}$ are shown in Figure 4. The composite oxygen isotope section from Holes $883 \mathrm{C}$ and $883 \mathrm{D}$ (from Keigwin, this volume) is also depicted. Although not identical, the $C$. davisiana davisiana abundance pattern in Core 1 (0-7.64 mbsf) contains many
Table 1. Coordinates and water depths of Leg 145 holes analyzed.

\begin{tabular}{cccc}
\hline Hole & Latitude & Longitude & $\begin{array}{c}\text { Water depth } \\
(\mathrm{m})\end{array}$ \\
\hline $881 \mathrm{~A}$ & $47^{\circ} 6.14^{\prime} \mathrm{N}$ & $161^{\circ} 29.49^{\circ} \mathrm{E}$ & 5531.1 \\
$881 \mathrm{~B}$ & $4^{\circ} 6.14^{\prime} \mathrm{N}$ & $161^{\circ} 29.49^{\prime} \mathrm{E}$ & 5530.8 \\
$881 \mathrm{C}$ & $47^{\circ} 6.13 \mathrm{~N}$ & $161^{\circ} 29.49^{\prime} \mathrm{E}$ & 5530.8 \\
$883 \mathrm{~B}$ & $51^{\circ} 11.91 \mathrm{~N}$ & $167^{\circ} 46.13^{\prime} \mathrm{E}$ & 2384.0 \\
$883 \mathrm{D}$ & $51^{\circ} 11.92 \mathrm{~N}$ & $167^{\circ} 46.11^{\prime} \mathrm{E}$ & 2385.5 \\
$887 \mathrm{~A}$ & $54^{\circ} 21.92 \mathrm{~N}$ & $148^{\circ} 26.77^{\prime} \mathrm{W}$ & 2631.2 \\
$887 \mathrm{~B}$ & $54^{\circ} 21.92 \mathrm{~N}$ & $148^{\circ} 26.78^{\prime} \mathrm{W}$ & 3635.9 \\
\hline
\end{tabular}

features recorded in the upper portions ( $\sim 5 \mathrm{mbsf})$ of cores from the subantarctic, North Pacific, and North Atlantic oceans (Fig. 2). All the records contain relatively low levels of $C$. davisiana davisiana in the uppermost sections (letter "a" on the $C$. davisiana davisiana curves), corresponding to oxygen isotopic Stage 1. Throughout oxygen isotope Stage 2 and into Stage 3,C. davisiana davisiana reaches a maximum in abundance. The AMS dates from Site 883D (Table 2) indicate that the youngest $C$. davisiana davisiana abundance peak $(\sim 1.1 \mathrm{mbsf})$ in Hole $883 \mathrm{~B}$ occurs within isotopic Stage 2. The major difference between the $C$. davisiana davisiana curve from Hole $883 \mathrm{~B}$ and those shown in Figure 2 is that the sequence from Hole $883 \mathrm{~B}$ does not clearly show the low $C$. davisiana davisiana values corresponding to isotopic Substages 5a and 5c (letters " $e_{1}$ " and "e $e_{2}$ " in Fig. 2) characteristic of most records from lower latitudes $\left(40^{\circ}-50^{\circ}\right)$. Although not evident in the sequences from the three cores shown in Figure 2, the high $C$. davisiana davisiana peak registered in Hole $883 \mathrm{~B}$ before abundance minimum " $\mathrm{e}_{3}$ " is present in curves from other North Pacific sites (Morley et al., 1982).

The first large gap in the oxygen isotope curve from Site 883 occurs post isotopic Stage 4. Although samples were taken throughout the bottom $2.5-\mathrm{m}$ section of Core 1 from Hole $883 \mathrm{~B}$, only the lowermost two samples contained the required number of Uvigerina to produce a reliable isotopic value. The $C$. davisiana davisiana record from Hole $883 \mathrm{~B}$, with its typical low values (similar to those of low abundance level "a") for the minimum (letter " $e_{3}$ ") corresponding to oxygen isotope Substage 5e, confirms that the isotopic values at the base of Core 1 from Hole 883D correspond to the glacial/interglacial transition (oxygen isotope Stage 6/5) and the earliest portion of the last interglacial (oxygen isotope Substage 5e).

The $C$. davisiana davisiana pattern throughout Core 2 and in the upper $\sim 2 \mathrm{~m}$ of Core 3 from Hole $883 \mathrm{~B}$ is very similar to that recorded for this species in other high-latitude records from the Pacific, Atlantic, and Southern oceans (Fig. 2). It would appear that this portion of Hole 883B contains a sediment record corresponding to oxygen isotope Stages 6 (letters "f" through "h"), 7 (letters "i" through "k"), 8 (letters "l" through "n"), 9 (letters "o" through "q"), 10 (letter "r"), and 11 (letter "s").

This identification and labeling of specific $C$. davisiana davisiana maxima and minima in Hole 883B below Core 1 is supported by biostratigraphic event information. The identification of the LO of $S$. curvirostris $(0.3 \mathrm{Ma})$ at $15.56 \mathrm{mbsf}$ indicates that the $C$. davisiana davisiana maximum (letter "n") recorded at this level corresponds to the early portion of oxygen Stage 8. Likewise, the LO of $S$. acquilonium $(0.35 \mathrm{Ma})$ at $18.26 \mathrm{mbsf}$ in Hole $883 \mathrm{~B}$ places this section of the core in late oxygen isotope Stage 11 and substantiates the lettering of the $C$. davisiana davisiana record in the upper $2 \mathrm{~m}$ of Core 3 . Therefore, it would appear that the early portion of the $C$. davisiana davisiana values corresponding to oxygen isotope Stage 9 (letter " $\mathrm{q}$ ") constitutes the missing portion of sediment lost at the core break between Cores 2 and 3 from Hole 883B.

In the composite isotopic section from Site 883 below the level identified as corresponding to the last interglacial maximum, a sequence of 10 values from Core 2 of Hole $883 \mathrm{C}$ (filled diamonds, Fig. 4) represents a portion of the sediment record lost at the core break between Cores 1 and 2 from Hole 883D. Numerous samples on either side of these 10 values from Hole $883 \mathrm{C}$ failed to contain the required 
Table 2. Biostratigraphic and magnetostratigraphic events and AMS dates from Sites $\mathbf{8 8 1}, \mathbf{8 8 3}$, and 887 .

\begin{tabular}{|c|c|c|c|}
\hline Hole & Event & $\begin{array}{l}\text { Depth } \\
\text { in core } \\
\text { (mbsf) }\end{array}$ & $\begin{array}{l}\text { Age } \\
\text { (Ma) }\end{array}$ \\
\hline $881 \mathrm{~B}$ & LO L nipponica sakaii & 2.65 & 0.05 \\
\hline $881 \mathrm{~B}$ & LOS , acquilonitum & 20.65 & 0.35 \\
\hline $881 \mathrm{~B}$ & LOS, universus & 24.50 & 0.45 \\
\hline $881 \mathrm{~B}$ & Brunhes/Matuyama & 46.50 & 0.78 \\
\hline $881 \mathrm{~B}$ & Matuyama/Jaramillo & 56.70 & 0.98 \\
\hline $881 \mathrm{C}$ & LO L nipponica sakaii & 2.61 & 0.05 \\
\hline $881 \mathrm{C}$ & LOS. universus & 23.00 & 0.45 \\
\hline $881 \mathrm{C}$ & Brunhes/Matuyama & 48.10 & 0.78 \\
\hline $881 \mathrm{C}$ & Matuyama/Jaramillo & 57.60 & 0.98 \\
\hline $883 \mathrm{~B}$ & LO L nipponica sakaii & 3.16 & 0.05 \\
\hline $883 B$ & LO S. curvirostris & 15.56 & 0.30 \\
\hline $883 \mathrm{~B}$ & LO S. acquilonium & 18.26 & 0.35 \\
\hline $883 \mathrm{D}$ & AMS date & 0.80 & $0.013630 \pm 0.000080^{\mathrm{a}}$ \\
\hline 883D & AMS date & 1.40 & $0.020330 \pm 0.000160^{b}$ \\
\hline $887 \mathrm{~A}$ & LO L nipponica sakaii & 3.53 & 0.05 \\
\hline $887 \mathrm{~A}$ & LO $S$. acquilonium & 22.73 & 0.35 \\
\hline $887 \mathrm{~A}$ & LOS. universus & 29.33 & 0.45 \\
\hline $887 \mathrm{~B}$ & LO S. acquilonium & 20.11 & 0.35 \\
\hline $887 \mathrm{~B}$ & LO $S$, universus & 25.29 & 0.45 \\
\hline
\end{tabular}

Notes: Ages for all but AMS dates from Shipboard Scientific Party (1993a), based on Cande and Kent (1992) time scale. LO = last occurrence,

a Calibrated age (in calendar years B.P.) is $0.014820 \mathrm{Ma}$.

${ }^{\mathrm{b}}$ Calibrated age (in calendar years B.P.) is $0.022880 \mathrm{Ma}$.

number of benthic foraminifers for isotopic analysis (Keigwin, this volume), so it is unclear whether this sequence from Hole $883 \mathrm{C}$ completely covers the sediment gap in Hole 883D. Core 2 from Hole $883 \mathrm{D}$ contains several intervals where it was not possible to acquire oxygen isotope measurements, one of which is $>3 \mathrm{~m}$. Thus, without the detail provided by the $C$. davisiana davisiana abundance pattern from Hole $883 \mathrm{~B}$, it would be extremely difficult to place the various pieces of this discontinuous isotopic record in their proper chronological positions (i.e., oxygen isotope minimum labeled Stage 7 could have as easily been identified as part of Stage 9).

\section{Site 887}

Hole $887 \mathrm{~B}$ was selected as the primary record at Gulf of Alaska Site 887 for high-resolution late Pleistocene paleoceanographic studies. Any missing sediment sequences in Hole $887 \mathrm{~B}$ were to be filled with short portions from Hole $887 \mathrm{~A}$, thereby producing a complete composite record of the last $0.5 \mathrm{~m}$.y. Detailed oxygen isotope analyses will be made at all levels where there are sufficient numbers of benthic foraminifers (T. Pedersen, pers. comm., 1995). Based on isotopic studies of sediments from piston cores taken near this site (T. Pedersen, unpubl. data, 1991), the oxygen isotope record from Site 887 will probably be as discontinuous and patchy as that from northwest Pacific Site 883.

The $C$. davisiana davisiana variations in Hole 887B are plotted in the right portion of Figure 5. Specific $C$. davisiana davisiana maxima and minima were identified based on the LOs of $S$. acquilonium and $S$. universus (Table 2). Because L. nipponica sakaii was present in sediments from the top of Core 2 but not in samples from the bottom of Core 1 , it was not possible to precisely locate the $\mathrm{LO}$ of this event in Hole $887 \mathrm{~B}$. The LO of $S$. acquilonium falls late within oxygen isotope Stage 11 ( C. davisiana davisiana minimum "s"). The LO of $S$. universus falls on the isotopic $12 / 11$ transition (between $C$. davisiana davisiana maximum " $\mathrm{x}$ " and minimum " $\mathrm{w}_{2}$ ").

Comparisons were also made of these identified maxima and minima with other $C$. davisiana davisiana records from the North Pacific, North Atlantic, and Southern oceans (Fig. 2). Although all the maxima and minima in the representative records shown in Figure 2 could not be identified in the $C$. davisiana davisiana curve from Hole $887 \mathrm{~B}$, enough features common to both the "standard" and Hole $887 \mathrm{~B}$ records were recognized, making it possible to determine the approximate position of most of the oxygen isotope stage boundaries (dashed lines in Fig. 5).

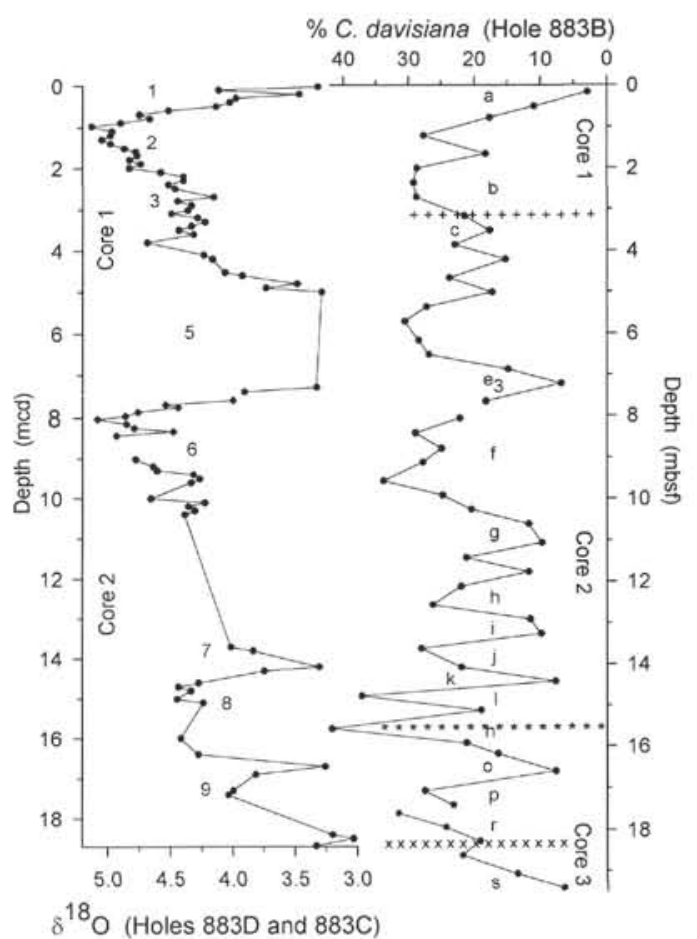

Figure 4. Correlation of oxygen isotope $\left(\delta^{18} \mathrm{O}\right)$ variations (Uvigerina sp. analyses; horizontal scale at bottom) in composite section from Holes $883 \mathrm{C}$ (filled diamonds) and 883D (filled circles) with $C$. davisiana davisiana abundance (relative percentage) pattern (horizontal scale at top) in Hole 883B (oxygen isotope data from Keigwin, this volume). Left vertical scale indicates composite depth in meters (mcd) for sections from Holes $883 \mathrm{C}$ and 883D; right vertical scale indicates depth in meters below seafloor ( $\mathrm{mbsf}$ ) for Hole 883B. Individual hydraulic piston cores from Holes $883 \mathrm{~B}$ and $883 \mathrm{D}$ are identified. Unconnected data points mark position of boundaries between individual cores. Oxygen isotope stages are numbered on the isotopic curve; specific $C$. davisiana davisiana minima and maxima are designated with letters. Line of +'s = last occurrence of radiolarian $L$. nipponica sakaii $(L$. sp. cf. $L$. grande); *'s = last occurrence of diatom S. curvirostris; $\times$ 's = last occurrence of radiolarian $S$. acquilonium.

After examination of the preliminary $C$. davisiana davisiana curve from Hole $887 \mathrm{~B}$, it became evident that, to ensure construction of the most complete composite section possible, we would have to produce this species' curve for almost the entire overlapping sequence $(\sim 0.5$ m.y.) from Hole 887A. The left curve in Figure 5 shows the $C$. davisiana davisiana pattern from Hole $887 \mathrm{~A}$, consisting of a continuous curve (except for core breaks) for the upper $30 \mathrm{~m}$ and a small 3-m sequence from the middle of Core 4. As was the case in Hole 887B, we identified the LOs of several radiolarian species (Table 2). The lettering of specific $C$. davisiana davisiana maxima and minima is based on the ages of these biostratigraphic events and correlation of the $C$. davisiana davisiana abundance variations in Hole $887 \mathrm{~A}$ with this species' abundance curve in other high-latitude cores from the Pacific, Atlantic, and Southern oceans (Fig. 2). As was the case in the record from Hole $887 \mathrm{~B}$, the approximate positions of oxygen isotope stage boundaries were determined for Hole 887A (dashed line in Fig. 5).

Comparison of the C. davisiana davisiana curve from Hole 887B with its counterpart in Hole 887A (Fig. 5) and with the "standard" records shown in Figure 2 clearly shows that in addition to the unrecovered sediment between cores, there are several portions of the recovered sediment sequence that appear to be disturbed. The missing sediment not recovered because of the coring gap between Cores 1 and 2 combined with the possible disturbed section indicated by the unidentified 2-m section from the top of Core 2, ensure that it will be quite difficult to acquire a quality oxygen isotope record for the inter- 
val in Hole $887 \mathrm{~B}$ extending from the last glacial maximum $(0.018$ $\mathrm{Ma})$ into the last interglacial $(0.087 \mathrm{Ma})(C$. davisiana davisiana abundance peak "b" through the unlabeled abundance peak above minimum " $e_{2}$ "). Another rather significant gap in the sediment record from Hole 887B exists between Cores 2 and 3, with the additional problem that the upper portion of Core 3 also appears to be disturbed. These combined effects indicate the interval from $\sim 0.18$ through 0.30 Ma (oxygen isotope Stages 7-8) was not recovered in Hole 887B. C. davisiana davisiana abundance minimum "u" and maximum " $v$ " are also evidently missing from Hole $887 \mathrm{~B}$, indicating that a $\sim 0.02-\mathrm{m} . \mathrm{y}$.sediment sequence was not recovered between Cores 3 and 4 .

It would appear that Hole $887 \mathrm{~A}$ contains a more complete record of the $C$. davisiana davisiana abundance pattern for the last $\sim 0.5$ m.y. when compared with Hole 887B. The portion of the $C$. davisiana davisiana sequence in the bottom $2.5 \mathrm{~m}$ of Core 1 (4.2-6.7 mbsf) most likely represents an expanded (stretched) section, making it difficult to positively identify $C$. davisiana davisiana abundance peak "d" and minimum " $\mathrm{e}_{1}$." Part of this interval may have been recovered again in the top of Core 2. Therefore, dashed lines indicating the approximate isotopic Stage 4/3 and 5/4 boundaries in sediments from Core 1 were not drawn. Approximately 0.05 m.y. of the $C$. davisiana davisiana record (part of $C$. davisiana davisiana maxima "l" and " $\mathrm{n}$ " and all of minimum "m" [early and middle portions of oxygen Stage 8]) was not recovered between Cores 2 and 3 . There is another small section of record missing between Cores 3 and 4 , as indicated by the incompleteness of $C$. davisiana davisiana maximum " $\mathrm{v}$ " (mid- and early isotopic Stage 11).

The apparent "completeness" of the $C$. davisiana davisiana record from Hole 887A permits identification and tagging of those sections in Hole $887 \mathrm{~B}$ that contain recognizable portions of the $C$. davisiana davisiana abundance pattern. Holes $887 \mathrm{~A}$ and $887 \mathrm{~B}$ exhibit nearly identical $C$. davisiana davisiana records over the upper $1.5 \mathrm{~m}$, with low abundance level "a" corresponding to the Holocene $(\geq 0.01 \mathrm{Ma})$ and high abundance level "b" marking the time of the last glacial maximum $(\sim 0.02 \mathrm{Ma})$. Comparison of both faunal curves from Site 887 indicates that, although the entire $C$. davisiana davisiana sequence corresponding to oxygen isotope Stage 5 ( $C$. davisiana davisiana minimum " $\mathrm{e}_{1}$ " through minimum " $\mathrm{e}_{3}$ ") is present in both holes, the record of the latest portion of this period seems to be disturbed in Hole $887 \mathrm{~B}$. The $C$. davisiana davisiana curve from Hole $887 \mathrm{~A}$ confirms that much of the interval between 0.18 and $0.30 \mathrm{Ma}$ is either missing or disturbed in Hole 887B. From the $C$. davisiana davisiana minimum "o" to the bottom of both curves, the $C$. davisiana davisiana pattern from Holes $887 \mathrm{~A}$ and $887 \mathrm{~B}$ is quite similar, with identical features in Hole 887 A occurring $\sim 3 \mathrm{~m}$ lower than in Hole $887 \mathrm{~B}$.

\section{Site 881}

Several holes were made at Leg 145 Site 881 to attempt to recover a complete Pliocene and Pleistocene section. We have used sections from three of these holes (881A, 881B, and 881C) in an effort to construct a complete sediment sequence of the $C$. davisiana davisiana abundance pattern for the last $1 \mathrm{~m} . \mathrm{y}$.

Hole $881 \mathrm{~B}$ was selected as the primary hole, analyzing only those sequences from Holes $881 \mathrm{~A}$ and $881 \mathrm{C}$ which would fill missing sections from Hole $881 \mathrm{~B}$. Much of these shorter sequences were provided by sediment from Hole $881 \mathrm{C}$ because Hole $881 \mathrm{~A}$ consisted of a single core.

The $C$. davisiana davisiana variations for the last $\sim 1$ m.y. for Holes $881 \mathrm{~B}, 881 \mathrm{~A}$, and $881 \mathrm{C}$ plotted vs. meters below seafloor are shown in Figures 6 and 7. In Holes 881B and 881C, the LOs of $L$. nipponica sakaii ( $L$. sp. cf. $L$. grande) $(0.05 \mathrm{Ma}), S$. acquilonium $(0.35 \mathrm{Ma})$ and $S$. universus $(0.45 \mathrm{Ma})$ were located as well as the Brunhes/Matuyama and Matuyama/Jaramillo magnetic boundaries (Table 2; Figs. 6, 7). Maxima and minima in C. davisiana davisiana were labeled in the upper 0.45 m.y. through comparison with the "standard" curves shown in Figure 2 and constrained by the three

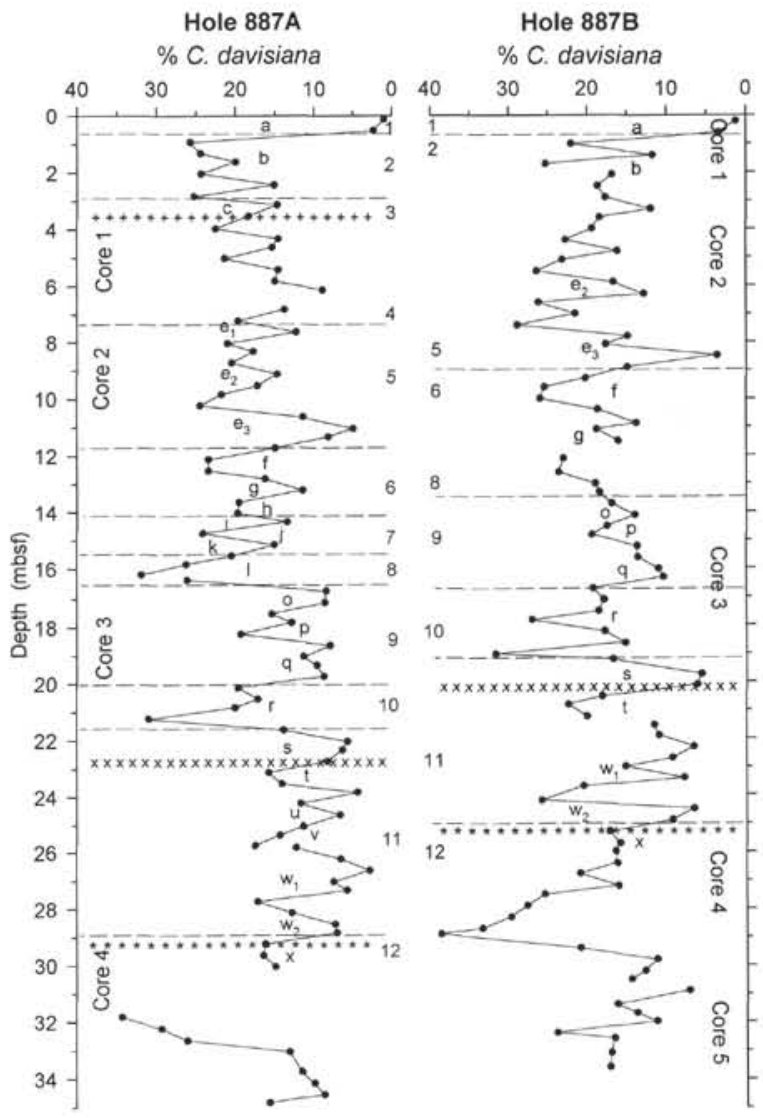

Figure 5. C. davisiana davisiana abundance variations (relative percentage) in Holes $887 \mathrm{~A}$ and $887 \mathrm{~B}$. Individual hydraulic piston cores from both holes are identified. Unconnected data points mark position of boundaries between individual cores. Left vertical scale indicates depth in meters below seafloor for Hole $887 \mathrm{~A}$; right vertical scale indicates depth in meters below seafloor for Hole 887 B. Specific $C$. davisiana davisiana minima and maxima are designated with letters. Approximate location of oxygen isotope stage boundaries (determined from correlation of $C$. davisiana davisiana records with oxygen isotope stratigraphy from North Atlantic [Morley and Hays, 1979] and subantarctic [Hays et al., 1976a]) indicated by dashed lines and numbered accordingly. Line of +'s = last occurrence of radiolarian $L$. nipponica sakaii $(L \mathrm{sp}$. cf. $L$. grande); ×'s = last occurrence of radiolarian $S$. acquilonium; *'s = last occurrence of radiolarian $S$. universus.

faunal datum levels. Oxygen isotope stage boundaries (dashed lines) were placed on the $C$. davisiana davisiana abundance pattern from these three holes from Site 881 based on previous published correlation of $C$. davisiana davisiana variations with oxygen isotope records in sediment sequences from the North Atlantic (Morley and Hays, 1979) and subantarctic (Hays et al., 1976a). Solid lines in Figures 6 and 7 connect equivalent points in Holes $881 \mathrm{~B}$ and $881 \mathrm{C}$ across core breaks in Hole $881 \mathrm{~B}$.

Examination of the $C$. davisiana davisiana curves labeled in the holes from Site 881 indicates that we were apparently unsuccessful in our attempt to construct a complete composite record of this species' abundance variations for the last $1 \mathrm{~m}$.y. None of the three records from Site 881 contains low abundance $C$. davisiana davisiana level " $\mathrm{e}_{2}$," suggesting that these cores are all missing a section of about $0.015 \mathrm{Ma}$ corresponding to oxygen isotope Substages $5 \mathrm{~b}$ and $5 \mathrm{c}$. With the exception of the ash layer that occurs within $C$. davisiana davisiana abundance peak "g," the record appears to be complete through the remainder of the last $0.45 \mathrm{Ma}$, with sediment from Hole $881 \mathrm{C}$ providing the section lost between Cores 2 and 3 in Hole 881B. 


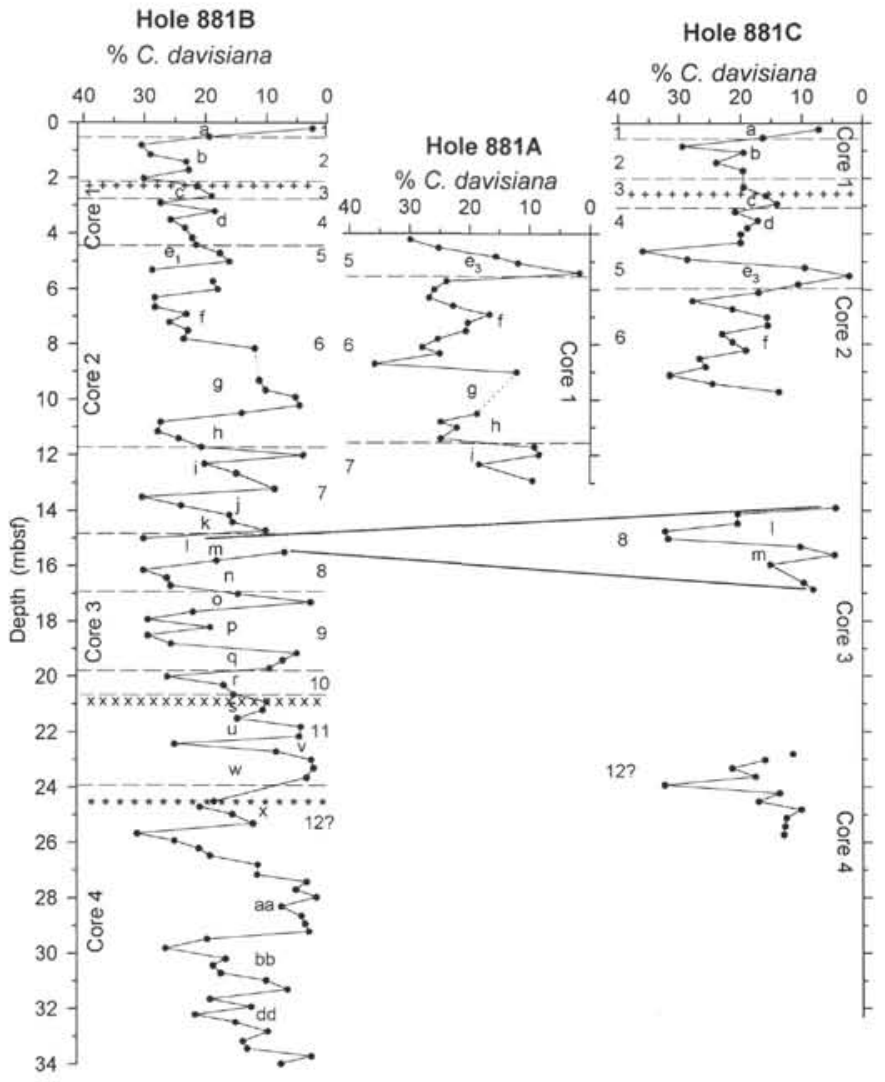

Figure 6. C. davisiana davisiana abundance variations (relative percentage) in Cores 1 through 4 from Holes $881 \mathrm{~B}, 881 \mathrm{~A}$, and $881 \mathrm{C}$. Hole $881 \mathrm{~B}$ was designated the primary core, with data analyzed from Holes $881 \mathrm{~A}$ and $881 \mathrm{C}$ only to fill missing sediment sequences in Hole 881B lost at core breaks. Individual hydraulic piston cores from each hole are identified. Unconnected data points mark position of boundaries between individual cores. Left vertical scale indicates depth in meters below seafloor for Hole 881B; center and right vertical scales indicate depth in meters below seafloor for Holes $881 \mathrm{~A}$ and $881 \mathrm{C}$, respectively. Specific $C$. davisiana davisiana minima and maxima are designated with letters. Approximate location of oxygen isotope stage boundaries (determined from correlation of $C$. davisiana davisiana records with oxygen isotope stratigraphy from North Atlantic [Morley and Hays, 1979] and subantarctic (Hays et al., 1976a]) indicated by dashed lines and numbered accordingly. Line of +'s = last occurrence of radiolarian L. nipponica sakaii (L. sp. cf. L. grande); X's = last occurrence of radiolarian S. acquilonium; *'s $=$ last occurrence of radiolarian $S$. universus. Dotted lines between data points in Core 2 of Hole 881B and in Core 1 of Hole 881 A show location of thick ash layer barren of radiolarians. Common levels between Holes $881 \mathrm{~B}$ and $881 \mathrm{C}$ bracketing core breaks in Hole $881 \mathrm{~B}$ are tied by solid lines.

Comparison of the $C$. davisiana davisiana abundance curves at Site 881 with this species' pattern in sediments from northwest Pacific DSDP Site 580 (Fig. 3) as well as with the "standard" records from the various high-latitude oceans (Fig. 2) shows that the patterns are quite similar. Low $C$. davisiana davisiana abundances (letter "a") characterize the post-Pleistocene in all the sequences. The youngest high abundance peak (letter "b") extends from late in oxygen isotope Stage 3 through Stage 2. In North Pacific sites (this study; Morley et al., 1982; Morley and Dworetzky, 1991), this abundance peak usually is marked by two, and sometimes three, prominent peaks of nearly the same magnitude. In all North Pacific sites, the LO of the radiolarian species $L$. nipponica sakaii ( $L$. sp. cf. $L$. grande) falls within $C$. davisiana davisiana minimum "c" (Morley and Dworetzky, 1991; Morley et al., 1982; Site 883, this study). The smaller abundance peak (letter "d"), directly below minimum "c", coincides with oxygen

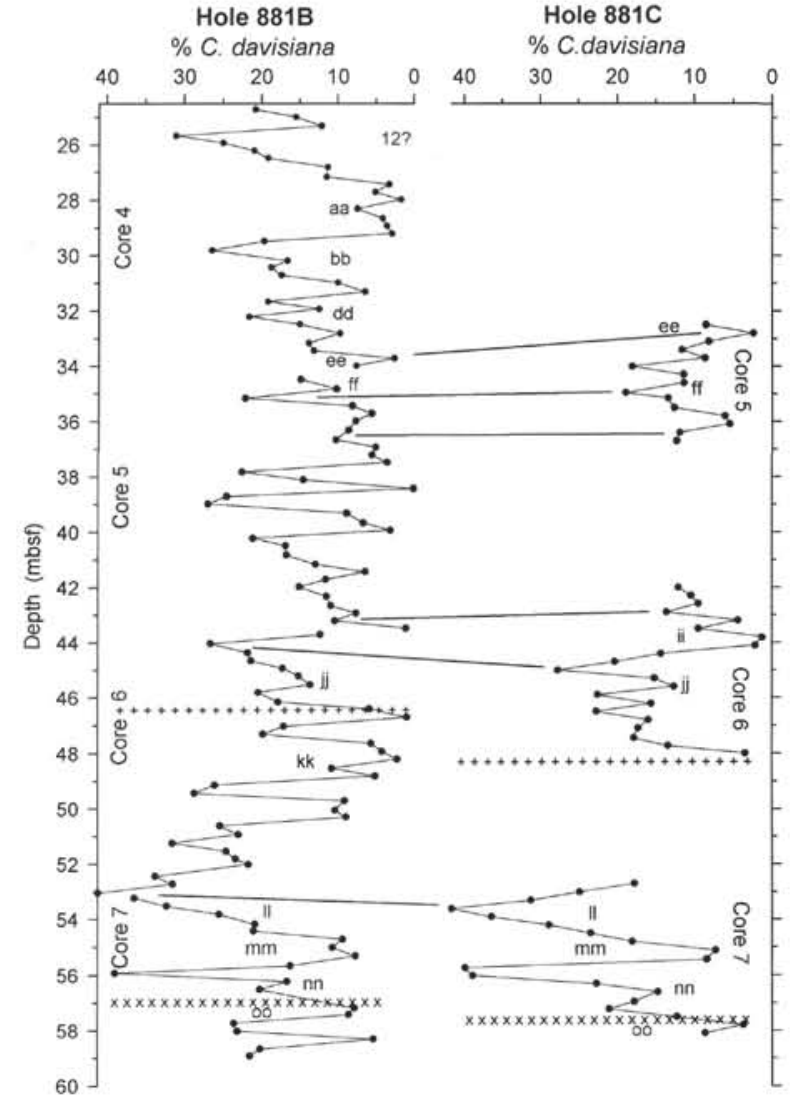

Figure 7. C. davisiana davisiana abundance variations (relative percentage) in Cores 4 through 7 from Holes $881 \mathrm{~B}$ and $881 \mathrm{C}$. Hole $881 \mathrm{~B}$ was designated the primary core, with data analyzed from Hole $881 \mathrm{C}$ only to fill missing sediment sequences in Hole $881 \mathrm{~B}$ lost at core breaks. Individual hydraulic piston cores from both holes are identified. Unconnected data points in curve from Hole $881 \mathrm{~B}$ mark position of boundaries between individual cores. Left vertical scale indicates depth in meters below seafloor for Hole $881 \mathrm{~B}$; right vertical scale indicates depth in meters below seafloor for Hole 881C. Specific $C$. davisiana davisiana minima and maxima are designated with letters. Line of + 's $=$ Brunhes/Matuyama boundary, and X's = Matuyama/Jaramillo boundary. Common levels between two holes bracketing core breaks in Hole $881 \mathrm{~B}$ are tied by solid lines.

isotope Stage 4 in the subantarctic (Hays et al., 1976a, b) and North Atlantic (Morley and Hays, 1979; Morley, 1983) oceans. C. davisiana davisiana low abundance minimum " $\mathrm{e}_{1}$ " is only present in the sequence from Hole $881 \mathrm{~B}$. This minimum coincides with oxygen isotope Substage 5a in the Southern (Hays et al., 1976a, b) and North Atlantic (Morley and Hays, 1979; Morley, 1983) oceans. Low abundance $C$. davisiana davisiana level " $e_{3}$ " is quite distinctive as it marks the only time within the last $0.15 \mathrm{Ma}$ when this species' abundances reach levels comparable with those registered in the Holocene (letter "a"). This minimum has been correlated with oxygen isotope Substage $5 \mathrm{e}$ in the Southern (Hays et al., 1976a, b), North Atlantic (Morley and Hays, 1979; Morley, 1983), and the North Pacific (Site 883 , this study) oceans. Below minimum " $\mathrm{e}_{3}$ ", C. davisiana davisiana abundances form a broad interval characterized by high values (letter "f"), which coincides with the younger half of oxygen isotope Stage 6 in the Southern (Hays et al., 1976a) and North Pacific (Site 883 , this study) oceans. Correlation of the oxygen isotope stratigraphy in cores from the subantarctic (Hays et al., 1976a) with the $C$. davisiana davisiana curve places the isotopic Stage 7/6 boundary on the transition between this species' abundance maximum " $h$ " and minimum "i." Abundance maximum " $\mathrm{j}$ " is a large peak in sites from the northwestern North Atlantic (Morley, 1983), and North Pacific 
(Morley and Dworetzky, 1991) oceans, and in the subantarctic (Hays et al., 1976a) where it has been correlated with the glacial interval (oxygen isotope maximum) within oxygen isotope Stage 7. The oxygen isotope Stage $8 / 7$ boundary falls between $C$. davisiana davisiana minimum " $\mathrm{k}$ " and maximum "l" in the subantarctic (Hays et al., 1976a) and in the North Pacific ocean (Site 883, this study). C. davisiana davisiana maxima "l" and " $\mathrm{n}$ " occur within isotopic Stage 8; with minima "o" and " $\mathrm{q}$ " of this species falling within oxygen isotope Stage 9 (Hays et al., 1976a; this study). The LO of S. acquilonium at 20.65 mbsf in Hole $881 \mathrm{~B}$ confirms that the coinciding $C$. davisiana davisiana minimum is letter "s", corresponding to late oxygen Stage 11 (Fig. 2). C. davisiana davisiana minimum "w" is positioned directly above the LO of $S$. universus (24.50 mbsf) in Hole $881 \mathrm{~B}$, with the transition between isotopic Stages 12 and 11 evidently occurring near the base of Core 3 in this hole.

Unfortunately, it does not appear as if sediment recovered from Hole $881 \mathrm{C}$ fills the missing sediment sequence between Cores 3 and 4 from Hole 881 B. Evidently, a significant interval (at least from 0.35 to $0.45 \mathrm{Ma}$ ) of the sediment record was lost between Cores 3 and 4 from Hole $881 \mathrm{C}$, as evidenced by the absence of $S$. acquilonium and S. universus in the oldest sample from Core 3 (single point at 22.8 mbsf, Fig. 6) and the presence of these two species in the youngest sample from Core 4 . Therefore, the possibility exists that there is a missing section of unknown length in our composite $C$. davisiana davisiana curve from Site 881 below the LO of $S$. universus $(0.45$ $\mathrm{Ma}$ ). Based on comparison of the $C$. davisiana davisiana curve from Hole $881 \mathrm{~B}$ with those from northwest Pacific DSDP Hole 580 (Fig. 3) and Core V20-120 (Morley et al., 1982; Fig. 2), it is probable that this missing portion, if indeed it is missing, represents a very small portion of this species' abundance maximum "x."

The common points between Holes $881 \mathrm{~B}$ and $881 \mathrm{C}$, indicated by the solid lines in Figure 7, show that our composite section is complete from the top of Core 4 in Hole 881B through the Matuyama/ Jaramillo magnetic boundary $(0.98 \mathrm{Ma})$ in Core 7 . Using this magnetic boundary as well as the Brunhes/Matuyama boundary, we have correlated abundance maxima and minima in our composite section from Site 881 (Figs. 6, 7) with that from northwest Pacific DSDP Hole 580 (Fig. 3). Positioned below $C$. davisiana davisiana maximum " $x$ " is a rather broad abundance minimum (letter "aa") in Hole 580 and Hole $881 \mathrm{~B}$. This feature is followed in both holes ( 580 and $881 \mathrm{~B}$ ) by two distinctive abundance peaks (letters "bb" and "dd"). The Brunhes/Matuyama boundary occurs within a $C$. davisiana davisiana minimum directly below a broad abundance maximum (letter "ij") composed apparently of two separate peaks. Directly above this maximum is a very low abundance level labeled "ii" (this sediment sequence only recovered from Hole $881 \mathrm{C}$ and Hole 580).

Between the Brunhes/Matuyama $(0.78 \mathrm{Ma})$ and Matuyama/ Jaramillo $(0.98 \mathrm{Ma})$ magnetic boundaries, there are a number of distinct maxima and minima in the $C$. davisiana davisiana abundance pattern from DSDP Hole 580 and our composite section from Site 881. The highest percentages of $C$. davisiana davisiana in the past 1 m.y. are recorded during the abundance maximum labeled "ll." Directly below this maximum abundance peak and just prior to the Matuyama/Jaramillo boundary there is a narrow couplet composed of a short minimum (letter "mm") in C. davisiana davisiana abundance and another maximum (letter "nn"). The Matuyama/Jaramillo magnetic boundary occurs within a $C$. davisiana davisiana minimum (letter "oo") in all three holes $(580,881 \mathrm{~B}, 881 \mathrm{C})$.

Therefore, although we did not totally succeed in our goal of constructing a continuous composite section of $C$. davisiana davisiana abundance variations for the last 1 m.y., all indications are that our record contains only two short gaps (mid oxygen Stage 5 and Stage 12). Both of these missing sections in our composite $C$. davisiana davisiana abundance pattern can be filled by insertion of appropriate intervals from existing sediment sequences from conventional piston cores.

\section{SUMMARY}

This study shows the advantages of having developed a highresolution stratigraphy for high-latitude sites containing low-carbonate sediments of Pleistocene age. We were able to identify missing sections in upper Pleistocene sediment sequences from both Sites 883 and 887 using a detailed stratigraphy based on the abundance variations of the radiolarian $C$. davisiana davisiana.

At Site 881 , we constructed the $C$. davisiana davisiana abundance pattern for much of the interval between $1 \mathrm{Ma}$ and the present. The $C$. davisiana davisiana abundance curve for the period between 0.5 and 1.0 Ma contains variations of similar magnitude and duration as those recorded in the latest Pleistocene. We have identified distinct $C$. davisiana davisiana maxima and minima in the older portion $(0.5-$ $1.0 \mathrm{Ma}$ ) of this curve from Site 881. This description and documentation of the $C$. davisiana davisiana abundance record beyond 0.5 Ma extends the use of this species' abundance pattern as a reliable alternative high-resolution stratigraphy in high-latitude sediment sequences to the mid-Pleistocene.

\section{ACKNOWLEDGMENTS}

Thanks to L. Keigwin for granting permission to publish the benthic oxygen isotope curve for Site 883 and for supplying the foraminifers for AMS dating. Samples for Hole 887B made available through T. Pedersen. Radiocarbon dating was supported in part by the U.S. Department of Energy at Lawrence Livermore National Laboratory under contract W-7405-Eng-48. We are grateful to I. Basov, D. Murray, and K. Takahashi for their thorough reviews of the manuscript.

Thanks to D. Rea, I. Basov, T. Janecek, and the other scientists and crew members of Leg 145 of the JOIDES Resolution for recovering the marine sediments that made this study possible. Funds for the post-cruise portion of this project provided by USSAC. Samples provided by the Ocean Drilling Program.

\section{REFERENCES}

Cande, S.C., and Kent, D.V., 1992. A new geomagnetic polarity time scale for the Late Cretaceous and Cenozoic. J. Geophys. Res., 97:13917-13951.

Donahue, J.G., 1970. Pleistocene diatoms as climatic indicators in North Pacific sediments. In Hays, J.D. (Ed.), Geological Investigations of the North Pacific. Mem.-Geol. Soc. Am., 126:121-138.

Hays, J.D., Imbrie, J., and Shackleton, N.J., 1976a. Variations in the Earth's orbit: pacemaker of the ice ages. Science, 194:1121-1132.

Hays, J.D., Lozano, J.A., Shackleton, N.J., and Irving, G., 1976b. Reconstruction of the Atlantic and western Indian Ocean sectors of the 18,000 B. P. Antarctic Ocean. In Cline, R.M., and Hays, J.D. (Eds.), Investigations of Late Quaternary Paleoceanography and Paleoclimatology. Mem.Geol. Soc. Am., 145:337-372.

Hays, J.D., and Ninkovich, D., 1970. North Pacific deep-sea ash chronology and age of present Aleutian underthrusting. In Hays, J.D. (Ed.), Geological Investigations of the North Pacific. Mem.-Geol. Soc. Am., 126:263-290.

Hays, J.D., and Shackleton, N.J., 1976. Globally synchronous extinction of the radiolarian Stylatractus universus. Geology, 4:649-652.

Kruglikova, S.B., 1976. Radiolarians in the upper Pleistocene sediments of the boreal and northern subtropical zones of the Pacific Ocean. Oceanology, 16:113-117.

Moore, T.C., Jr., 1973. Method of randomly distributing grains for microscopic examination. J. Sediment. Petrol., 43:904-906.

Morley, J.J., 1983. Identification of density-stratified waters in the latePleistocene North Atlantic: a faunal derivation. Quat. Res., 20:374-386.

, 1985. Radiolarians from the Northwest Pacific, Deep Sea Drilling Project Leg 86. In Heath, G.R., Burckle, L.H., et al., Init. Repts. DSDP, 86: Washington (U.S. Govt. Printing Office), 399-422.

\footnotetext{
Abbreviations for names of organizations and publications in ODP reference lists follow the style given in Chemical Abstracts Service Source Index (published by American Chemical Society).
} 
Morley, J.J., and Dworetzky, B.A., 1991. Evolving Pliocene-Pleistocene climate: a north Pacific perspective. Quat. Sci. Rev., 10:225-238.

Morley, J.J., and Hays, J.D., 1979. Cycladophora davisiana: a stratigraphic tool for Pleistocene North Atlantic and interhemispheric correlation. Earth Planet. Sci. Lett., 44:383-389.

1983. Oceanographic conditions associated with high abundances of the radiolarian Cycladophora davisiana. Earth Planet. Sci. Lett., 66:63-72.

Morley, J.J., Hays, J.D., and Robertson, J.H., 1982. Stratigraphic framework for the late Pleistocene in the northwest Pacific Ocean. Deep-Sea Res. Part A, 29:1485-1499.

Morley, J.J., and Shackleton, N.J., 1978. Extension of the radiolarian Stylatractus universus as a biostratigraphic datum to the Atlantic Ocean. Geology, 6:309-311.
Robertson, J.H., 1975. Glacial to interglacial oceanographic changes in the northwest Pacific, including a continuous record of the last 400,000 years [Ph.D. dissert.]. Columbia Univ., New York.

Shipboard Scientific Party, 1993a. Explanatory notes. In Rea, D.K., Basov, I.A., Janecek, T.R., Palmer-Julson, A., et al., Proc. ODP, Init. Repts., 145: College Station, TX (Ocean Drilling Program), 9-33.

, 1993b. Site 881. In Rea, D.K., Basov, I.A., Janecek, T.R., PalmerJulson, A., et al., Proc. ODP, Init. Repts., 145: College Station, TX (Ocean Drilling Program), 37-83.

Date of initial receipt: 5 April 1994

Date of acceptance: 31 August 1994

Ms 145SR-108 